\title{
COMMENTS
}

\section{FDR's COURT-PACKING PLAN: A SECOND LIFE, A SECOND DEATH}

\author{
WiLliam E. LeUChTENBURG*
}

The story of Franklin D. Roosevelt's Court-packing plan is a twicetold tale. ${ }^{1}$ Every history of America in the twentieth century recounts the familiar chronicle-that in February of 1937, FDR, in response to a series of decisions striking down New Deal laws, asked Congress for authority to add as many as six Justices to the Supreme Court, only to be outwitted by the Court itself when Chief Justice Charles Evans Hughes demonstrated that Roosevelt's claim that the Court was not abreast of its docket was spurious; when the conservative Justice Willis Van Devanter retired, thereby giving the President an opportunity to alter the composition of the bench; and when, above all, the Court, in a series of dramatic decisions in the spring of 1937, abandoned its restricted conception of the scope of the powers of both state and national governments. In short, it is said, Roosevelt's Court-packing plan went down to defeat because, in the catchphrase that swept Washington that spring, "a switch in time saved nine."2

All true enough. But what this familiar account leaves out is that Roosevelt, apparently vanquished in the spring of 1937, brought out another Court scheme-little different from the first-in early summer, and, despite all that had gone on before, came very close to putting it through.

* Professor of Legal History, Duke University School of Law; William Rand Kenan, Jr., Professor of History, University of North Carolina at Chapel Hill; author of FRANKLIN D. RoOSEVELT AND THE NEW DEAL, $1932-1940$ (1963). This essay was originally presented in a slightly different form on May 14, 1984, as the annual address to the Supreme Court Historical Society in the Restored Court Chamber of the Capitol in Washington, D.C.

1. The standard accounts are J. Alsop \& T. CATledge, The 168 Days (1938) and L. BAKer, BACK to BACK: The DUAL Between FDR AND THE SUPREME Court (1967). See also Leuchtenburg, The Origins of Franklin D. Roosevelt's "Court-Packing" Plan, 1966 SuP. CT. REV. 347; Leuchtenburg, Franklin D. Roosevelt's Supreme Court "Packing" Plan, in EsSAYS ON THE NEW DEAL 69 (H. Hollingsworth \& W. Holmes ed. 1969).

2. Letter from Edward Corwin to Homer Cummings (May 19, 1937) (available in Corwin Manuscripts, Princeton University). 
One can well understand, though, how the traditional version has found such acceptance, for by early June of 1937 Roosevelt appeared to be thoroughly whipped. After the events of May-Van Devanter's announcement, an adverse vote by the Senate Judiciary Committee, the Social Security decisions ${ }^{3}$-each poll his agents took of attitudes in the Senate showed the same result: the President no longer had the votes to enact his Court bill. ${ }^{4}$ On Capitol Hill, the debonair chairman of the Senate Judiciary Committee, Henry Fountain Ashurst, who was covertly opposed to the legislation, was heard humming an old tune: "Massa's in the Cold, Cold Ground."s

With his plan foundering, Roosevelt heard still more dismaying news: the Vice President was skipping town. At the end of a Friday afternoon Cabinet meeting, John Nance Garner, who was counted on by the President to hold party regulars in line, revealed abruptly that he was going home to Texas that very weekend and that he would be away for quite a while. ${ }^{6}$ Over the weekend the Vice President tossed a fishing rod into his sixteen-cylinder limousine, told his wife to climb in, and directed his chauffeur to head for the Southwest. ${ }^{7}$ His departure created a sensation, for it marked the first occasion in more than a third of a century that Garner had left the capital while Congress was in session. ${ }^{8}$ Though it is by no means clear that the Vice President's departure was related to his sentiments about Court packing, his behavior flashed a signal to other Democrats in Washington: that one did not have to put up any longer with FDR's exotic ideas and even more exotic advisors, that it was perfectly all right, good for the country and even good for the party, to turn one's back on the White House. 9

3. Helvering v. Davis, 301 U.S. 619 (1937) (upholding the Social Security Act's provision of "Federal Old-Age Benefits"); Steward Mach. Co. v. Davis, 301 U.S. 548 (1937) (upholding Social Security tax on employers).

4. N.Y. Herald Tribune, June 10, 1937, at 5, col. 1; N.Y. Times, June 7, 1937, at 6, col. 1; N.Y. Herald Tribune, June 6, 1937, at 24, col. 1; id.. June 5, 1937, at 1, col. 1; N.Y. Times, June 4, 1937, at 1, col. 8 .

5. N.Y. Herald Tribune, June 6,1937 , at 28 , col. 1 .

6. Time, June 21, 1937, at 15.

7. Clippings (available in John Garner Manuscripts, Scrapbook 13, Archives, University of Texas, Austin, Tex.); see also Time, supra note 6, at 15.

8. B. Timmons, Garner of TeXas 216-21 (1948).

9. B. Donahoe, Private Plans and Public Dangers 49 (1965); J. Farley, Jim FarLEY'S STORY 83-86 (1948); Letter from Josiah W. Bailey to Charles D. Hilles (Nov. 30, 1938) (available in Hilles Manuscripts, Box 229, Yale University); Letter from Turner Catledge to Joseph W. Alsop (Nov. 11, 1937) (available in Alsop Manuscripts, Box 2, Library of Congress); Homer Cummings Diary (June 11, 1937) (available in Cummings Manuscripts, University of Virginia); Breckinridge Long Diary (June 14, 1937) (available in Long Manuscripts, Library of Congress); see Detroit News, June 16, 1937, at 22, col. 3 (available in Prentiss Brown Scrapbooks, Brown Manuscripts, Michigan Historical Collections, Ann Arbor, Mich.). 
Two days after Garner took French leave, Roosevelt received a much bigger jolt: the long-awaited adverse report of the Senate Judiciary Committee. ${ }^{10}$ Of the ten Senators who signed the document, seven came from FDR's own party, but almost from the opening word the report showed the President's proposal no mercy. The plan, the report said, revealed "the futility and absurdity of the devious."11 An effort "to punish the Justices" whose opinions were resented, the bill was "an invasion of judicial power such as has never before been attempted in this country." 12 If enacted, it would create a "vicious precedent which must necessarily undermine our system." 13

Without ever directly saying that Roosevelt was another Hitler, the report called attention to "the condition of the world abroad" and maintained that any attempt to impair the independence of the judiciary led ineluctably to autocratic dominance, "the very thing against which the American Colonies revolted, and to prevent which the Constitution was in every particular framed." 14 Consequently, the report concluded, "[w]e recommend the rejection of this bill as a needless, futile, and utterly dangerous abandonment of constitutional principle." 15 In a final thundering sentence that, before the day was out, would be quoted in every newspaper in the land, the report ended: "It is a measure which should be so emphatically rejected that its parallel will never again be presented to the free representatives of the free people of America."16

Recognizing that a document signed by so many prominent Democrats was an immense boon to their cause, opposition organizations saw to it that the pamphlet had the widest possible circulation. A committee headed by the publisher Frank Gannett, which got hold of the document three days before it was issued, airmailed a copy to every daily newspaper in America before the release date; Methodists hostile to the plan sent copies to more than one hundred thousand clergymen. ${ }^{17}$ The Government Printing Office soon found that it had a runaway best seller. Thirty thousand pamphlets were sold to the public in less than a month while

10. Senate Comm. on the Judiciary, ReORganization of THE Federal Judiciary, S. REP. No. 711, 75th Cong., 1st Sess. 1 (1937).

11. Id. at 10.

12. Id. at 11 .

13. Id. at 13 .

14. Id. at 15 .

15. Id. at 23.

16. Id.

17. Letter from Rev. Ralph E. Nollner to Amos R.E. Pinchot (Oct. 13, 1937) (available in Amos Pinchot Manuscripts, Box 60, Library of Congress). 
Congressmen gobbled up another seventy thousand for free distribution. ${ }^{18}$

The report gained much of its power from its stinging invective. The constitutional commentator Burton Hendrick observed: "The gentlemen who wrote this Report give the President little credit for sincerity. . . . The accusation is one of the most formidable ever framed against an American President." 19 In like manner, a newspaper correspondent wrote: "History-minded persons who have delved into the records were unable to discover an instance where a President was so scathingly indicted in a congressional committee report." The Senators, he said, plainly implied that the President had practiced deceit. ${ }^{20}$

Since the seven Democrats who signed the report included seasoned veterans of party warfare, it seemed reasonable to suppose that they had deliberately chosen to express their views in a way that would provoke a clean break with the President. In attacking Roosevelt's motives and in refusing to concede any merit whatsoever to the bill, they had chosen a brutally divisive tactic. Nobody expected the President to forgive them for their words, however much he might have excused their deeds. "No more harshly worded document was issued forth . . . within the memory of the present generation in Washington," wrote the Boston Herald's Washington correspondent. "There are no involved sentences-all are direct, hard and intentional blows. . . . If the so-called conservative wing of the Democratic party persists in bucking the President on his every move from now on, the adverse committee report may well prove their document of secession." 21

Delighted by all this evidence of internecine bickering, Roosevelt's hardcore opponents believed that, at long last, they had him on the run. A new Gallup survey found that support for judicial reform had been sliding at the rate of about one percent a week down to a new low of forty-one percent. 22 FDR's opponent in the 1936 campaign, Alf Landon, wrote: "His right wing is smashed and in retreat[;] his center is confused and wavering[,] his left wing advanced so far it is out of touch with his center," 23 and the columnist Raymond Clapper jotted in his diary: "This

18. S. Williamson, Frank GanNetT 194 (1940); Letter from Homer H. Gruenther to John Bauer (June 30, 1937) (available in Maury Maverick Manuscripts, Box 5, University of Texas Library, Austin, Tex.).

19. Hendrick, Senate Report, No. 711, SATURDAY REV., June 26, 1937, at 7.

20. Hayden, Court Bill Becomes a Wraith, Detroit News, June 15, 1937, at 1, col. 1.

21. Boston Herald (article by Henry Ehrlich; date unknown) (available in H. Styles Bridges Manuscripts, Scrapbook 56, New England College).

22. Washington Post, June $20,1937, \S 3$, at 5, col. 1 .

23. Letter from Alf Landon to Arthur Vandenberg (June 24, 1937) (available in Vandenberg Manuscripts, Personal-Confidential File, Clements Library, University of Michigan). 
seems most serious ebb of Rvt sentiment since he took office."24 As adjournment fever swept Capitol Hill, the administration feared it could not withstand the movement to table the Court legislation and pack up and go home.

To many observers it seemed improbable that Roosevelt could salvage anything from the debris. The report, wrote the Kansas editor William Allen White, "delivered the coldest wallop that the President has had to take. He can't stand another one."25 Five thousand miles away, in London, Anthony Eden received what appeared to be the final verdict. His Majesty's ambassador at Washington, Sir Ronald Lindsay, informed him: "Seven Democratic Senators have committed the unforgivable sin. They have crossed the Rubicon and have burned their boats; and as they are not men to lead a forlorn hope one may assume that many others are substantially committed to the same action. One can only assume that the President is fairly beaten."'26

But at precisely this point, when his fortunes had sunk to their lowest, Roosevelt brought about an astonishing recovery that breathed new life into the apparently moribund idea of Court packing. The President understood that if he was to save the Court bill, he had to move quickly. ${ }^{27}$ So when the Senate majority leader, Joseph T. Robinson, suggested that the President meet with Democratic officials for a weekend of frank discussion, he readily agreed. Asked which party leaders he wanted to invite, Roosevelt grinned and said every Democrat in Congress was a party leader; all of them should be asked, all four hundred and more of them. ${ }^{28}$ Robinson knew just the place: the Jefferson Islands Club in Chesapeake Bay, a former bootleggers' hideout that was now a Democratic fish and game club. ${ }^{29}$

On June 16, while Washington continued to hum with talk of the Judiciary Committee report filed two days before, ${ }^{30}$ the President, as he had so often in the past, diverted attention to the White House by announcing to 407 surprised Democratic Congressmen that they were in-

24. Raymond Clapper Diary (June 23, 1937) (available in Clapper Manuscripts, Library of Congress).

25. Letter from William Allen White to David Hinshaw (June 17, 1937) (available in William Allen White Manuscripts, Series C, Box 268, Library of Congress).

26. Letter from R.C. Lindsay to Anthony Eden (June 22, 1937) (available in Public Record Office, London, No. 554E, F.O. 371, 20668 (A4640/542/45)).

27. Pearson \& Allen, Washington Merry-Go-Round, Cleveland Press, June 23, 1937, § 2, at I, col. 7.

28. Time, June 28, 1937, at 9; N.Y. Times, June 17, 1937, § 1, at 7, col. 5; see Washington Post, June 17, 1937, at 1, col. 2.

29. Breckinridge Long Diary (June 14, 1937) (available in Long Manuscripts, Library of Congress).

30. See id. 
vited to picnic with him over the weekend of June 25 . At 9 a.m. that Friday, a flotilla of Navy patrol boats carrying more than one hundred Congressional Democrats and government officials weighed anchor in Annapolis harbor. On each of the next two days, another relay of Congressmen, chosen by lot, was ferried to the island. ${ }^{31}$

When the Congressmen arrived at the island, not knowing what to expect, they discovered that a whiz-bang entertainment had been arranged. They swam in the nude, shot clay pigeons, fished, swapped stories, played pinochle, knocked a softball around, and enjoyed the amenities of the julep room. ${ }^{32}$ They sang such sentimental ballads as "The Old GOP, She Ain't What She Used to Be" and "My Sweetheart's a Mule in the Mines." 33 There was even a hog-calling contest. ${ }^{34}$ One reporter wrote: "Horrified members of Congress clamped their hands to their ears as three members of the House rent the peaceful air with wails, bellows and u-la-las. The trees were reported to shiver. The waters of the bay quivered and farmers on the mainland barely restrained their pigs from plopping off to a drowning." 35 At long tables on the lawn, Congressmen ate a shore lunch of crabs, potato salad, cold cuts, apple pie, and iced tea. In the afternoon they sought the shade of the clubhouse or drank cold beer under the trees. ${ }^{36}$

The Congressmen found the President in a jovial mood and altogether accessible. For six hours each day he sat in a big chair under a mulberry tree near the water's edge and greeted scores of guests by first name, even those he had never met before. ${ }^{37}$ Dressed in old white linen trousers, coatless and tieless, his soft shirt opened at the neck, he seemed completely at ease, ${ }^{38}$ and reporters on press boats circling the island could hear his laugh booming across the water. ${ }^{39}$

31. N.Y. Herald Tribune, June 22, 1937, at 5, col. 1; Watertown (N.Y.) Daily Times, June 22, 1937 (available in Royal Copeland Scrapbooks, Michigan Historical Collections, University of Michigan); see also Buffalo Evening News, June 22, 1937, at 16, col. 3.

32. Time, July 5, 1937, at 7-8; N.Y. Herald Tribune, June 28, 1937, at 1, col. 4; N.Y. Times, June 26, 1937, at 1, col. 3; id.. June 17, 1937, §1, at 7, col. 5; Lawrence Lewis Diary (June 26, 1937) (available in Lewis Manuscripts, State Historical Society of Colorado, Denver, Colo.).

33. Washington Post, June 26, 1937, at 8, col. 3 .

34. N.Y. Herald Tribune, June 28,1937 , at 6 , col. 3.

35. Id. at 1 , col. 4.

36. Detroit News, June 28, 1937, at 14, col. 2; id. at 27, col. 1 .

37. Washington Post, Junc 27, 1937, at 10, col. 1; N.Y. Times, June 26, 1937, at 1, col. 3; Lawrence Lewis Diary (June 26, 1937) (available in Lewis Manuscripts, State Historical Society of Colorado, Denver, Colo.); Breckinridge Long Diary (June 27, 1937) (available in Long Manuscripts, Library of Congress).

38. N.Y. Times, June $27,1937, \S 1$, at 20, col. 4; id., June 26, 1937, at 4, col. 5; Washington Post, June 26, 1937, at 8, col. 2.

39. Washington Post, June 26, 1937, at 8, col. 4. 
The Jefferson Island frolic proved to be an inspired idea. Almost everyone agreed, noted a correspondent for the New York Times, "that the President had done himself a "world of good." "40 Roosevelt, the Cleveland Press had remarked before the picnic, "is a gambler for small gains. That is, he never overlooks the slightest chance when engaged in a big legislative battle, as he has often demonstrated. Who can tell . . . that out of his three-day family party he might not clinch the few votes needed to put over a compromise on his court plan . . ?"41 By many accounts, that is just what the President did. ${ }^{42}$

After the camaraderie of Jefferson Island, not a few Democratic Congressmen began to have second thoughts about the Senate Judiciary Committee report. Foes of the President had been picturing him as a man consumed by rancor and determined to secure revenge. Instead, the legislators had found a jolly innkeeper who radiated geniality. He had greeted the authors of the vitriolic committee report magnanimously and had given every impression of "a large soul rising above contumely." 43 The Washington columnist Arthur Krock commented:

The dramatization was perfect; the hero played his role flawlessly; and the audience began to forget his faults and indignantly to recall his aspersed virtues.

"It reminded me," said a cynical spectator today, "of what happens in the gallery when, on the stage, a long-suffering son slaps the face of his father. Forgetting the provocation the father gave, remembering only instinct and precept, the audience turns on the son for going too far." 44

No longer was the opposition boasting of an early victory. At Whitehall, Anthony Eden now received very different intelligence from His Majesty's envoy at Washington. In a follow-up dispatch Sir Ronald Lindsay informed him:

The meeting of the Democratic Congressmen on Jefferson Island . . . had rather surprising results, for the Roosevelt charm was turned onto them as through a hose pipe and they have returned to the Capital in a far more malleable spirit. . . . The feelings which induced seven Dem-

40. Catledge, Outing Promises Gain in Good-Will, N.Y. Times, June 28, 1937, at 5, col. 1; see also Breckinridge Long Diary (June 27, 1937) (available in Long Manuscripts, Library of Congress); Letter from Daniel Roper to William E. Dodd (June 30, 1937) (available in Roper Manuscripts, Box 15, Duke University); Letter from Daniel Roper to Key Pittman (June 28, 1937) (available in Pittman Manuscripts, Box 14, Library of Congress).

41. Cleveland Press, June 17, 1937, at 15, col. 5.

42. See, e.g., Breckinridge Long Diary (June 27, 1937) (available in Long Manuscripts, Library of Congress).

43. Krock, One Result of the Jefferson Islands Picnic, N.Y. Times, June 29, 1937, at 20, col. 5.

44. Id. 
ocratic Senators to sign the adverse report . . . are no longer in fashion. ${ }^{45}$

It was during this period of newfound euphoria that the administration put together its revised Court bill. In its new form, the legislation authorized the President to appoint one additional Justice per calendar year for each member of the Supreme Court who had reached the age of seventy-five. (Originally, the age had been seventy, and they could be named all at once.) Since there were currently four Justices seventy-five or over, the bill would empower him to name four new Justices, if none of these men left the bench, as well as one Justice to fill the Van Devanter vacancy, but the total of five could not be reached until the beginning of 1940.46 Under this so-called "compromise," FDR lost very little. The most immediate effect of the measure would be to permit Roosevelt by the beginning of January, 1938-only six months away-to add three Justices to the Court: one for the 1937 calendar year, one for the 1938 calendar year, and one to fill Van Devanter's slot. The principle of Court enlargement was very much intact.

The prospects for enacting this new bill appeared very promising. All through the month of June, Joe Robinson had been piecing together a majority. At his direction his chief lieutenants-Sherman Minton, Hugo Black, and Alben Barkley-worked the Senate corridors, buttonholing their Democratic colleagues, and, when they sensed someone was weakening, bringing him to the majority leader's office to see if a commitment could be extracted. ${ }^{47}$ Robinson and his aides found that a number of Senators were not so hostile to this new version as they had been to the original bill, and the White House brought pressure on others. "Wait until the heat is turned on," FDR's agent on Capitol Hill, Tommy Corcoran, told a Senator in the troubled days after the Judiciary Committee report was released. "What do you mean by turning on the heat?" the Senator asked. With a disarming grin, Corcoran replied, "The heat of reason." 48

In the final days of June the majority leader held three caucuses, each attended by some fifteen Senators, at which he explained in detail the nature of the new legislation, which was nearing finished form, and implored his fellow Democrats not to desert the leader of their party. $\mathrm{He}$

45. Letter from R.C. Lindsay to Anthony Eden (July 6, 1937) (available in Public Record Office, London, No. 592E, F.O. 371, 20668 (A4931/542/45))

46. Homer Cummings Diary (June 18 - July 2, 1937) (available in Cummings Manuscripts, University of Virginia); Stanley Reed, Memorandum for the Attorney General (June 18, 1937) (available in President's Secretary's File-Supreme Court, Franklin D. Roosevelt Library, Hyde Park, N.Y.).

47. J. ALSOP \& T. CATLEDGE, supra note 1, at 227-28.

48. Johnston, White House Tommy, Saturday Evening Post, July 31, 1937, at 6. 
ended each session by stating that he would regard every man in the room as pledged to vote for the revised measure unless someone spoke up on the spot. Only one man did, and he indicated simply that he wanted more time. When the process was completed, Robinson was able to give the President the news he most vvanted to hear: he had his majority. ${ }^{49}$

Most independent observers agreed.50 Though the press was overwhelmingly antagonistic to the proposal, Washington correspondents credited Robinson with some fifty commitments. "[T]he best guessing," wrote Raymond Clapper in his column, "is that the new . . . court-enlargement bill . . . will get through . . . ."51 Privately, the opposition conceded that these reckonings were correct. In a confidential tally sheet prepared for the leading lobbyist against the Court plan, the publisher Frank Gannett, the Nebraska Senator Edward Burke admitted that if the roll were called right away, FDR would wind up the winner, fifty-two to forty-four. ${ }^{52}$

To be sure, the opposition, with its estimated forty-four votes, might well mount a filibuster, but many doubted that a filibuster would succeed. Roosevelt's opponents, who had been charging him with perverting the democratic process, would be in an embarrassing position if they sought to deny the people's representatives in Congress an opportunity to vote and thereby contrived the triumph of the will of a minority. ${ }^{53}$ Nor did no-holds-barred hostilities appeal to party moderates. "Among the conciliatory Democrats," noted the New York Times, the filibuster was "losing favor. They have apparently come to the conclusion that the

49. J. Alsop \& T. CATledge, supra note 1, at 240-41; N.Y. Times, July 3, 1937, at 1, col. 4; Letter from Grenville Clark to William H. King (June 29, 1937) (available in Clark Manuscripts, Series VII, Box 2, Dartmouth College); Letter from Charles D. Hilles to the Viscount Knollys (July 12, 1937) (available in Hilles Manuscripts, Box 212, Yale University); Letter from W. K. Hutchinson to Alf Landon (July 23, 1937) (available in Landon Manuscripts, Box 85, Kansas State Historical Society, Topeka, Kan.); see Letter from James A. Farley to Claude G. Bowers (July 1, 1937) (available in Farley Manuscripts, Box 5, Library of Congress); see also N.Y. Times, June 5, 1937, at 1, col. 6; Letter from George W. Hutsmith to Edward Gluck (June 1 \& 4, 1937) (available in Clark Manuscripts, Series VII, Box 2, Dartmouth College).

50. See Colmer, Congressional Sidelights (available in Colmer Manuscripts, Box 150, University of Southern Mississippi); Letter from Clarence Hancock to Joseph F. Graydon (June 26, 1937) (available in Hancock Manuscripts, Box 1, George Arents Research Library, Syracuse University); Letter from Kenneth McKellar to Charles T. Pennebaker (July 10, 1937) (available in McKellar Manuscripts, Box 97, Memphis Public Library, Memphis, Tenn.).

51. Clapper, In the Capital, Cleveland Press, July 7, 1937, at 15, col. 7.

52. Burke's tally of roll call ten days before final vote on Court bill (available in Frank Gannett Manuscripts, Box 16, Cornell University).

53. N.Y. Times, July 6, 1937, at 1, col. 5; id., July 4, 1937, at 1, col. 3; Letter from H. Styles Bridges to Robert P. Bass (Apr. 7, 1937) (available in Bass Manuscripts, Box 46, Dartmouth College); Letter from Hiram Johnson to Garret W. McEnerney (July 7, 1937) (available in Johnson Manuscripts, Bancroft Library, University of California, Berkeley, Cal.). 
party would not present a pretty spectacle to the country by engaging in that kind of warfare." 54

A national periodical that had been singlemindedly hostile to Court packing from the start summed up the melancholy situation for its cause. At no time in the history of successful filibusters could the foes of a piece of legislation count so many Senators in their ranks as were aligned against the Court bill, observed Business Week. ${ }^{55}$ Unhappily, though, the measure still might be adopted. Business Week explained:

[D]espite the size of the opposition, and the ease with which they could prevent a vote being reached by Christmas[], were they anything like as determined as were the much smaller number who fought Woodrow Wilson on the Versailles treaty, no one [could] be sure of the outcome. Too many of them are not willing to run a real, organized filibuster. Too many of them are uncertain whether they would be justified in the eyes of their constituents. ${ }^{56}$

When the "Great Debate" on Court packing finally opened in July, a full five months after FDR's original message, a number of commentators thought that Joe Robinson had put together a winning combination. Despite all the talk of the opposition's delaying tactics, the Washington bureau of the Portland (Maine) Press Herald reported: "General opinion is the substitute will pass, and sooner than expected, since votes enough to pass it seem apparent, and the opposition cannot filibuster forever."57 Such forecasts, though, rested wholly on the ability of Joe Robinson to bully, persuade, or cajole enough reluctant Democrats to go along with him. Without the majority leader, FDR's cause was doomed.

Robinson knew that a very difficult struggle lay ahead, and he concluded that there was only one way he could prevail-by turning the Great Debate into an endurance contest. ${ }^{58}$ As early as May the columnist Mark Sullivan had reported:

Some of the President's partisans say he'll win on the court issue as soon as he gets the help of a powerful ally, namely, hot weather-and Congressmen want to go home. Grimly they add, "The White House is air-conditioned; the homes of the Congressmen are not; and Washington in summer is a very hot climate." 59

54. N.Y. Times, July 4,1937 , at 2 , col. 7.

55. How to Bust Court Filibuster? BUSINEsS WeEk, July 17, 1937, at 14.

56. Id.

57. Portland Press-Herald, July 7, 1937, at 13, col. 6 (available in Wallace White Manuscripts, Box 81, Library of Congress).

58. See Detroit Free Press, July 11, 1937, at 2, col. 1.

59. Sullivan, Where Is New Deal Heading?: Contradictory Direction Held Confusing to a Baffled Capital, N.Y. Herald Tribune, May 16, 1937, §2, at 2, col. 1. 
In truth, the prospect of being trapped in the capital through all of July and August and even beyond was enough to make strong men quail, and one-third of the Senate was over sixty. ${ }^{60}$

Washington's heat had a quality of unpleasantness that had won it an international reputation. The British Foreign Office categorized the climate in the American capital as "sub-tropical,"61 and in 1937 Noel Coward, recalling a 1925 tryout of The Vortex, wrote:

In later years I have travelled extensively. I have sweated through the Red Sea with a following wind and a sky like burnished steel. I have sweated through steamy tropical forests and across acrid burning deserts, but never yet, in any equatorial hell, have I sweated as I sweated in Washington. . . . The city felt as though it were dying. There was no breeze, no air, not even much sun. Just a dull haze of breathless discomfort through which the noble buildings could be discerned, gasping like nude old gentlemen in a steam room. The pavement felt like grey nougat and the least exertion soaked one to the skin. ${ }^{62}$

Just as Robinson had anticipated, a heat wave struck in the first week of the Great Debate, as torrid weather seared the eastern two-thirds of the nation. ${ }^{63}$ Bridges and roads buckled under the blazing sun, and in Tuckahoe, New York, Babe Ruth toppled over on a golf course and had to be treated by a physician for heat exhaustion. ${ }^{64}$ In the capital that day a Congressman wrote a friend, "Please remember that people in Washington are committing suicide to escape the heat,"65 and Senator McNary informed his sister, "We are having a hot spell and the weather is just as hot as ...., at least as hot as I think it is."66 Thousands of Washingtonians fled the city for relief in the mountains of Maryland and Virginia, but the Congressmen were condemned to remain in a steamy city that saw the thermometer holding at eighty-two degrees at midnight. ${ }^{67}$

Robinson knew that he did not have the two-thirds of the Senate required to impose cloture, but he surmised that there were limits to the

60. See N.Y. Times, July 15, 1937, § 1, at 1, col. 5; Detroit Free Press, July 11, 1937, at 2, col. 1; N.Y. Times, May 10, 1937, $§ 1$, at 1, col. 7; Letter from George B. McClellan to George H. Moses (May 23, 1937) (available in Moses Manuscripts, Box 4, New Hampshire Historical Society, Concord, N.H.).

61. W. Manchester, The Glory and the Dream 4 (1974).

62. N. Coward, Present Indicative 219-20 (1937).

63. N.Y. Herald Tribune, July $10,1937, \S 1$, at 1 , col. 5 .

64. Id., July 11, 1937, § 1, at 1, col. 1 .

65. Letter from Thomas Amlie to Alfred M. Bingham (July 10, 1937) (available in Bingham Manuscripts, Box 1, Yale University).

66. Letter from Charles McNary to Mrs. W.T. Stolz (July 10, 1937) (available in McNary Manuscripts, Box 1, Library of Congress).

67. See The Sunday Star, July 11, 1937, § A, at 1, col. 8; The Evening Star, July 10, 1937. § A. at 1, col. 5 . 
price his Democratic colleagues would pay to balk the President, and he was determined to keep raising that price. He could do so by insisting on strict adherence to the rules, moving on to Saturday sessions, and requiring evening and all-night meetings. ${ }^{68}$ Although the words were never spoken, the assumption behind Robinson's maneuvers was that if Senators continued to be obstinate, they would do so at the risk of their lives. ${ }^{69}$

Death had arrived unseasonably early that year. Before the opening session of the seventy-fifth Congress had convened, South Dakota's Senator Peter Norbeck was gone. ${ }^{70}$ By March, Congressman Charles W. Tobey was writing a former New Hampshire governor about the situation in the House: "Death has taken four of our members so far this year, and there is a sense of pressure constantly as one carries on here."71 In April Senator Nathan Bachman of Tennessee had died. ${ }^{72}$ Yet no one could be certain that Death was a friend of Court packing. Two Senators were undergoing treatment at Washington's Naval Hospital, and both were counted on the administration side of the ledger. There were even grounds for concern about Robinson himself, though few knew how serious they were. ${ }^{73}$

On the opening day of the Great Debate, Robinson made an aggressive two-hour speech that carried the fight to the enemy. His face an angry purple, his voice bellowing, his arms pawing the air, both feet stamping the floor, Robinson gave the appearance of an enraged bull. ${ }^{74}$ When the opposition Senators, like so many banderilleros, tormented him with pointed questions, he roared all the louder and charged around the floor as though it were a plaza de toros. ${ }^{75}$

Throughout the afternoon, Robinson, though finding it hard to choke off his wrath, appeared ready to go round after round with his antagonists, but, altogether unexpectedly, his presentation came to a precipitate end in a curious, even shocking, fashion. After talking for some two hours, the majority leader reached into his pocket for a cigar and

68. Cleveland Press, July 14, 1937, at 14, col. 1 .

69. See N.Y. Herald Tribune, May 16, 1937, § 2, at 2, col. 1.

70. Id., July 15, 1937, at 3, col. 5 .

71. Letter from Charles W. Tobey to Robert and Edith Bass (Mar. 23, 1937) (available in Robert P. Bass Manuscripts, Box 46 (R-Z folder: Arizona, 1937), Dartmouth College).

72. N.Y. Herald Tribune, July 15, 1937, at 3, col. 5 .

73. Dr. Henry J. Rutherford, Case History (available in Bernard Baruch Manuscripts, Princeton University); see also Los Angeles Times, June 24, 1937, § 1, at 6, col. 5 (available in Royal Copeland Scrapbooks, Michigan Historical Collections, University of Michigan).

74. Cleveland Press, July 14, 1937, at 14, col. 1; Evening Journal \& N.Y. American, July 14, 1937, at 2, col. 1.

75. 81 CONG. REC. 6787-91 (1937); J. ALSOP AND T. CATLEDGE, supra note 1, at 225-26; N.Y. Herald Tribune, July 7, 1937, § 1, at 1, col. 1 . 
struck a match to light it. Since striking a match on the Senate floor was, as one writer noted, "frowned upon almost as severely as striking a senator," 76 his colleagues stared at him in disbelief. His face, usually florid, turned ashen, and he seemed not to know quite where he was. $\mathrm{He}$ spoke a few words with the match in his hand, but, as it began to burn his fingers, he flung it to the floor and stamped it out. When Burke tried to ask him yet another question, Robinson said abruptly, "No more questions today. . . . Good-bye." 77

That odd note of farewell signalled what was to come. Over the next several days, Robinson had a hard time enduring both the enervating weather and the relentless assaults on his bill in the Senate chamber. Little more than a week after the Great Debate began, he left the Capitol at the end of the day's proceedings to make his way through the heat to his apartment in the Methodist Building across the plaza. On the next morning his maid entered the apartment and found Senator Robinson sprawled on the floor. He had been dead since midnight. ${ }^{78}$

Robinson's death sent shock waves through the Senate. ${ }^{79}$ On the day that the majority leader's body was found, the implacable anti-New Deal Democrat Royal Copeland, a physician, told his colleagues:

My fellow Senators, I am sorry sometimes that I ever studied medicine. Nearly 50 years have elapsed since I received that coveted diploma; but the embarrassment of medical knowledge is that many times it discloses to the medical man in the face and bearing of a friend the warning his dissolution is near at hand.

Mr. President, I say in all seriousness to my brethren the menace is here in this Chamber today. ${ }^{80}$

Copeland, whom New Dealers called "the ancient mariner," said he saw death written on the countenances of others in the Senate if Congress did not adjourn right away. ${ }^{81}$ The legislators did not need such admonitions to remind them of the ubiquity of death. Secretary of the Interior Harold Ickes commented in his diary: "There are a lot of men in the Senate no longer young who, in their mind's eye, probably pictured themselves

76. Clapper, In the Capital, Cleveland Press, July 7, 1937, at 15, col. 7; see TiME, July 19, 1937, at 10 .

77. 81 Cong. Rec. $6797-98$ (1937); Time, July 19, 1937, at 10.

78. J. Alsop \& T. Catledge, supra note 1 , at 267; T. CATledge, MY Life AND the Times 96 (1971); Time, July 26, 1937, at 10; N.Y. Herald Tribune, July 15, 1937, at 1, col. 8; N.Y. Times. July 15,1937 , at 1 , col. 8 .

79. See Tucker, Behind the News, Poughkeepsie Eagle News, July 24, 1937 (available in Royal Copeland Scrapbooks, Michigan Historical Collections, University of Michigan); N.Y. Times, July 15, 1937, at 1, col. 8 .

80. 81 CONG. Rec. 7153 (1937).

81. Id.; see also Cleveland Press, July 15, 1937, at 16, col. 6. 
found dead on bathroom floors from heart ruptures." 82

Determined to exploit this obsession to the fullest, foes of the judiciary bill accused the President and his New Deal cronies of nothing less than manslaughter. "Joe Robinson was a political and personal friend of mine," declared Senator Burton K. Wheeler. "Had it not been for the Court Bill he would be alive today. I beseech the President to drop the fight lest he appear to fight against God."83 Wheeler's statement revealed the poor judgment that was to characterize other of his public utterances. "Your bad taste," a Massachusetts mayor wired him, "is surpassed only by your conceit in assuming the role of God's spokesman." 84

But Wheeler's "ghoulish" remarks reflected a widespread apprehension that, as the Philadelphia Inquirer claimed, "[d]eath has assumed leadership in the Senate." 85 A reader of the Washington Post wrote: "The death of Senator Robinson, chief advocate of Roosevelt's court packing scheme, indicates that the Divine Power which spread the fogs to cover the movements of the hard pressed colonial army of the Revolution is still guarding the three-pillared edifice which those heroes built." ${ }^{86}$ Not everyone found these florid deductions persuasive. "I do not take much stock in the contention that God was taking a hand in this Court controversy," remarked a former governor of North Carolina. "If He were, I think probably He would have struck in another direction." 87

That acerbic remark revealed what many Senators had come to feel-that the acrimony was getting altogether out of hand. One morning Senator Minton received a bullet in the mail wrapped in a two-footlong piece of white scrap paper with the printed penciled message: "Sen. Sherman Minton. Don't mistake. I am educated. If you support Roosevelt's court bill we will get you-you dirty rubber stamp." The communication ended with an obscenity. ${ }^{88}$ On that same day Congressmen received a mimeographed flyer asking, "What will be gained by the passage of this bill, should thousands of citizens, with blood in their eyes, converge upon the Capital of Our Nation, and exact the retribution which is rightfully and justly theirs?" 89

82. 2 H. ICKeS, The SECrET Diary OF Harold L. ICKes 172 (1953-54).

83. N.Y. Times, July 15,1937 , at 13 , col. 8 .

84. Id., July 16, 1937, at 2, col. 4.

85. N.Y. Herald Tribune, July 15, 1937, at 4, col. 3 (quoting the Philadelphia Inquirer); see also United States News, July 19, 1937 (available in Jesse Jones Manuscripts, Box 332, Library of Congress).

86. Letter to the Editor, Washington Post, July 19, 1937, at 6, col. 4.

87. Letter from O. Max Gardner to B.B. Gossett (July 16, 1937) (available in Gardner Manuscripts, Box 15, Southern Historical Collection, University of North Carolina, Chapel Hill, N.C.).

88. Washington Daily News, July 21, 1937, at 2, col. 4.

89. Letter from the Vigilantes and Affiliated Organizations U.S.A. to "Congressman" (July 20, 1937) (available in Sam Hobbs Manuscripts, University of Alabama, Tuscaloosa, Ala.). 
In this overcharged atmosphere, Senators who had been tenuously committed to the Court plan only by ties to Senator Robinson concluded that the time had come to bail out. On the afternoon of July 21 , several of the first-year Senators, after conferring for two hours, reached a crucial decision-that the struggle must be brought to an immediate end. That judgment meant that on one afternoon the opposition had gained five votes, giving the forces for recommital an absolute majority for the first time. .0 "After the self-delivery of the freshmen Senators, we had fifty or fifty-one votes," the opposition Senator Hiram Johnson confided, "but we did not have them until then." 11 By nightfall, the administration Senators knew that it was all over except for the formal burial ceremonies. "They've got the votes. It's up to them," Minton conceded. "I guess if we get anything through, it will be nothing more than the picture of the Supreme Court on a postage stamp." 92

Roosevelt's attempt to reorganize the judiciary, which had outlived so many countermoves-the Chief Justice's testimony, "the switch in time," Van Devanter's retirement-could not survive the loss of Robinson. To be sure, the resistance to the Court bill in Congress, especially from Hatton Sumners, the powerful chairman of the House Judiciary Committee, almost certainly meant that the President would have to agree to further compromise. But with the majority leader's influence he could probably have preserved the essence of Court packing. Historians are distrustful of explanations that rest on a single episode, and properly so. Yet after all that had happened since early February, it was, in the final analysis, not the impact of Supreme Court decisions or broad social forces that brought about the defeat of Court packing, but the death of Joe Robinson, an altogether fortuitous event.

On the morning of July 22, 1937, Vice President Garner, now back in Washington, chaired a meeting of Senate leaders to see what could be salvaged from the wreckage. "There is no use kidding yourselves," he told the FDR loyalists. "No matter what your ideas are, everybody with any sense knows that all proposals with reference to the Supreme Court

90. Interview with Prentiss Brown (July 7, 1965); see Detroit News, July 21, 1937, at 1, col. 3 (available in Prentiss Brown Scrapbooks, Brown Manuscripts, Michigan Historical Collections, University of Michigan); N.Y. Herald Tribune, July 21, 1937, at 1, col. 8; Washington Post, July 21, 1937, at 1, col. 8; Typescript, Press Release, July 21, 1937 (available in Overton Manuscripts, Box 2, Louisiana State University, Baton Rouge, La.); Letter from John Overton to Richard W. Leche et al. (July 22, 1937) (available in Overton Manuscripts, Box 2, Louisiana State University, Baton Rouge, La.).

91. Letter from Hiram Johnson to John Francis Neylan (July 24, 1937) (available in Johnson Manuscripts, Bancroft Library, University of California, Berkeley, Cal.).

92. N.Y. Times, July 22, 1937, at 2, col. 2. 
are out of the window."93 Oblivious to the fact that he was addressing a Senate committee that included a sizeable component of Republicans, the Vice President, his eyes brimming with tears, pleaded for party harmony. "We must not give the President any kicks in the face which we can avoid," Garner said. "He is still head of the party."94

But Wheeler and his allies had every intention of kicking Roosevelt in the face. Angrily dismissing Barkley's effort to get the committee to agree to leave the Administration's bill on the calendar, so that the President would escape an explicit defeat, the Wheeler faction insisted that the measure be recommitted, and without delay. ${ }^{95}$ Barkley won only two concessions-the words "Supreme Court" would not be spoken in the Senate chamber and there would be no roll call to embarrass the President and his followers. ${ }^{96}$

Having forced the Administration Senators to agree to eat crow, the President's adversaries required that one of FDR's supporters cook the bird too. They wanted the motion to bury the bill introduced not by Wheeler but by Barkley. When the new majority leader refused, his Kentucky colleague, Senator Logan, was stuck with the unpalatable assignment. At two o'clock that afternoon, Logan rose laboriously to his feet to request the Senate to recommit the bill he had sponsored.97 The chore was even more painful than he had anticipated, for in expectation of being in on the kill, foes of the measure, who thronged the Capitol in such record numbers that lines extended all the way down the stairs to the doors of the building, occupied every seat in the galleries, and members of the House crowded the divans lining the walls of the room. Logan carried out his part of the bargain. Now the opponents were to do their part-permit a rapid disposition of the matter without debate, mention of the Supreme Court, or a record vote. ${ }^{98}$

But the stage managers of this charade reckoned without the Republican Senator from Oregon, Charles McNary. The minority leader did not mean to let the Democrats off easily. He insisted on a roll call. ${ }^{99}$ As one historian has written, "So the first pledge would be broken. The

93. L. BAKER, supra note 1, at 265; see also Allen, Roosevelt's Defeat-The Inside Story, 145 The NATION 123, 124 (1937); 2 H. ICKES, supra note 82, at 171; B. Timmons, supra note 8, at 224.

94. Detroit Free Press, July 23, 1937, at 4, col. 3; see Louisville Courier-Journal, July 23, 1937, at 1 , col. 8 .

95. Vandenberg, The Biography of an Undelivered Speech, Saturday Evening Post, Oct. 9, 1937, at 32; N.Y. Times, July 23, 1937, § 1, at 2, col. 4; N.Y. Herald Tribune, July 23, 1937, at 2, col. 2.

96. L. BAKER, supra note 1, at 266-67; A MANY-COLORED TOGA 379 (G. Sparks ed. 1962); see NEWS-WEEK, July 31, 1937, at 5.

97. 81 ConG. REC. 7375 (1937); Detroit Free Press, July 23, 1937, at 4, col. 2.

98. J. Alsop \& T. CATLEDGE, supra note 1, at 289-92.

99. N.Y. Times, July 23, 1937, § 1, at 2, col. 4. 
Republicans did not feel bound by any agreements Burton Wheeler might have made that morning in the Judiciary Committee. They had used him well. Now they discarded him."100

Before the roll could be called, Hiram Johnson made an inquiry that shattered the second feature of the accord. To get around mention of the words "Supreme Court," Logan had employed the circumlocution "judicial reform." Johnson now wanted to know what "judicial reform" referred to. "Does it refer to the Supreme Court or to the inferior courts?" Disconcerted, Logan replied: "I might say to the Senator from California that the Committee on the Judiciary this morning had an understanding that we did not think it was proper to embrace in the motion what it should refer to." Johnson would not be put off. "The Supreme Court is out of the way?" he persisted. Logan conceded, "The Supreme Court is out of the way."101

And though a meaningless roll call still lay ahead, it was at this moment that Roosevelt's second effort at Court packing, an endeavor that for quite some time appeared destined to be crowned with success, came to an end. Arms outstretched, his eyes fixed on the galleries, Senator Johnson cried, "Glory be to God."102

100. L. BAKER, supra note 1 , at 272.

101. 81 CONG. REC. 7381 (1937); L. BAKER, supra note 1, at 272-73; Maddox, Roosevelt vs. The Court, America History Illustrated, Nov. 1969, at 4, 10; N.Y. Herald Tribune, July 23, 1937. at 2, col. 2.

102. N.Y. Herald Tribune, July 23, 1937, at 1, col. 8 . 